\title{
Poverty Alleviation, Education and Economic Growth in Indonesia
}

Uti Rachel Setyoasih, Sri Harnani

(STIE Jaya Negara Tamansiswa Malang)

\begin{abstract}
This study examines government spending on education, economic growth and poverty in Indonesia. Where investment in education and economic growth reflected in GDP is calculated in USD and poverty is calculated per person or poor population using the mobile average autoregression method using secondary data from world banks. We find that education is able to reduce the number of poor people in Indonesia.
\end{abstract}

Keywords : Poverty Alleviation, Indonesia, Education

JEL Classification : C0, J24,J64

\section{Background}

Education is important in poverty alleviation. Education has long been recognized by most economic researchers as important for poverty alleviation. Quality education and equal distribution of education have a positive impact on economic growth, equal distribution of income and poverty alleviation (Wang,2020).

Improving the quality of education certainly requires investment from government spending to procure public goods in the form of schools and educational support facilities and infrastructure. Education is a cost that sometimes also has to be borne by the community. Education is proven to be able to increase human capital and improve skills, knowledge and human self-development (Pamuk,2018).

Human capital is very important for economic development and improving the welfare of society. Increased human capital as a result of the role of education in educating the nation's life. Human capital has an impact on improving population performance (Fischer \& Strauss,2021).

This study investigates government spending on education, economic growth and poverty. Where investment in education and economic growth reflected in GDP is calculated in USD and poverty is calculated per person or poor population.

\section{Literature Review}

In general, there are two kinds of education in Indonesia, namely formal education, known as school. Non-formal education such as private lessons or religion-based education such as Islamic boarding schools. Both formal and non-formal education provide their own color in the development of Indonesian human capital (Tan,2012). 
Early childhood education plays an important role in character building and early provisions to embrace an increasingly established education and improve children's knowledge and skills. Children with various interests and talents certainly need different kinds of education. Each person's role will be different depending on the skills and talents that each person has (Mafukata,2020).

The diversity of education and increased talent training in the informal education sector supports formal education that is standardized. Access to education and education costs is a must so that it can be reached by all people so that everyone has the same opportunity to get education and increase the human capital of everyone since early stage. Regarding the role in society, of course, it is adjusted to the skills and knowledge obtained from childhood or learning to adulthood and having entered the world of work (Topidi,2020).

Poverty that should be eliminated in society so that people can get a decent life. And everyone gets the same opportunity to improve their welfare. Education is a way that can be taken to alleviate poverty and distribute income even though it requires a long time in the process of developing human capital through educational mechanisms (Stern et al,2020).

\section{Research Method}

This study examines government spending on education, economic growth and poverty in Indonesia. Where investment in education and economic growth reflected in GDP is calculated in USD and poverty is calculated per person or poor population using the moving average autoregression method with the following equation:

$\mathrm{GDP}_{\mathrm{t}}=\mathrm{C}_{\mathrm{t}}+\beta_{1} \mathrm{P}_{\mathrm{t} 1}+\beta_{2} \mathrm{Ed}_{\mathrm{t} 2}+\mathrm{e}_{\mathrm{t}}$

Where,

GDP = Gross Domestic Product

$\mathrm{C}=$ Constant

$\mathrm{P}=$ Poverty

Ed $=$ Education

$\mathrm{e}=$ Error Term

The data source comes from the World Bank.

\section{Result and Discussion}

The estimation results are as follows:

$\mathrm{GDP}=1.97943292443 \mathrm{e}+12+4.33170339321 * \mathrm{ED}-17989.3580567 * \mathrm{P}$

From the estimation results, education (Ed) is positively related to gross domestic gross (GDP) and negatively related to poverty. This proves that education through the mechanism of increasing human capital is proven to be able to reduce poverty in Indonesia. Table 1 illustrates the estimation results as follows: 
Table 1. Estimation Results

\begin{tabular}{|l|r|r|r|r|}
\hline Variable & Coefficient & Std. Error & t-Statistic & Prob. \\
\hline C & $1.98 \mathrm{E}+12$ & $4.37 \mathrm{E}+11$ & 4.530642 & 0.0003 \\
\hline ED & 4.331703 & $9.23 \mathrm{E}-01$ & 4.690558 & $2.00 \mathrm{E}-04$ \\
\hline P & -17989.36 & $5.32 \mathrm{E}+03$ & -3.382455 & $3.50 \mathrm{E}-03$ \\
\hline R-squared & 0.980726 & \multicolumn{2}{|c|}{ Mean dependent var } & $2.03 \mathrm{E}+12$ \\
\hline Adjusted R-squared & 0.978458 & S.D. dependent var & $7.30 \mathrm{E}+11$ \\
\hline S.E. of regression & $1.07 \mathrm{E}+11$ & Akaike info criterion & 53.76971 \\
\hline Sum squared resid & $1.95 \mathrm{E}+23$ & Schwarz criterion & 53.91907 \\
\hline Log likelihood & -534.6971 & \multicolumn{4}{|c|}{ Hannan-Quinn criter. } & 53.79887 \\
\hline F-statistic & 432.5055 & \multicolumn{3}{|c|}{ Durbin-Watson stat } \\
\hline Prob(F-statistic) & \multicolumn{3}{|c|}{0.880297} \\
\hline
\end{tabular}

Based on the estimation results described in Table 1., it can be seen that the R-square is very high so that education in Indonesia quantitatively shows that it is able to reduce the number of poor people in Indonesia significantly and can be accounted for with a $98 \%$ level of truth.

\section{Conclusion}

Education is able to increase human capital, where human capital can be used to improve their welfare. Education is very important for poverty alleviation programs and enhancing economic growth. Education can effectively reduce the number of poor people in Indonesia.

\section{Reference :}

Fischer,G.,Strauss,R.(2021).Europe's Income, Wealth, Consumption, and Inequality. Oxford : Oxford University Press

Mafukata,M.A.(2020).Impact of Immigration and Xenophobia on Development in Africa. Hershey : IGI Global

Pamuk,E.(2018).Uneven Centuries: Economic Development of Turkey since 1820. Princeton : Princeton University Press

Stern,S., Del Mar,M. ,Meyler,B.(2020).The Oxford Handbook of Law and Humanities. Oxford University Press

Tan,C.(2012).Islamic Education and Indoctrination: The Case in Indonesia.London : Routledge

Topidi,K.(2020).Law and Religious Diversity in Education: The Right to Difference.London : Taylor \& Francis Group

Wang,X.(2020).Towards 2030 - China's Poverty Alleviation and Global Poverty Governance.Cham : Springer 